\title{
Karakteristik Penyelesaian Tindak Pidana Secara Informal Melalui Peradilan Adat
}

\author{
Fitriati
}

DATA NASKAH

Masuk: 6 Oktober 2016

Diterima: 14 November 2017

Terbit: 1 Desember 2017

KORESPONDEN PENULIS:

Fakultas Hukum Universitas Eka Sakti Padang

JI. Veteran Dalam No. 26 B Padang fitriati1974@yahoo.co.id

\begin{abstract}
Law enforcement can't be done only by formal means but also through informal. $O$ ne of the existing legal issues is the occurrence of criminal offenses. $M$ any crime cases in the administration are resolved by informal channels through various methods applied to each region. The objective of the research is to analyze the effectiveness of informal settlement of criminal cases through customary court. This research is a sociological law research, using primary and secondary data. The results were analyzed qualitatively. Based on the results of the research, it is found that the process of settling criminal acts through informal channels is a form of local wisdom in the process of law enforcement. Form of informal settlement of crime is through deliberation of nagari, adat court, adat conspiracy, direct action by society in the form of social sanction. The customary justice here is not institutionalized justice as is customary in formal law. The reason why the formal path is chosen because it is considered more effective and efficient in terms of time, procedures and costs.

K eywords; C rime, informal, customary justice, community
\end{abstract}

\section{ABSTRAK}

Penegakan hukum tidak dapat dilakukan hanya dengan cara formal saja tapi juga dapat dilakukan melalui jalur informal. Salah satu persoalan hukum yang ada adalah terjadinya tindak pidana. Banyak kasus tindak pidana di pemerintahan nagari yang diselesaikan dengan jalur informal melalui berbagai metode yang diterapkan pada masing-masing daerah tersebut. Tujuan penelitian adalah menganalisis efektifitas penyelesaian kasus tindak pidana secara informal melalui peradilan adat. Penelitian ini merupakan penelitian hukum sosiologis, dengan mengunakan data primer dan sekunder. $\mathrm{H}$ asil penelitian dianalisis secara kualitatif. Berdasarkan hasil penelitian ditemukan bahwa proses penyelesaian tindak pidana melalui jalur informal tersebut merupakan suatu bentuk kearifan 
lokal masyarakat dalam proses penegakan hukum. Bentuk penyelesaian tindak pidana secara informal tersebut adalah melalui musyawarah nagari, peradilan adat, pemufakatan adat, tindakan langsung oleh masyarakat berupa pemberian sanksi sosial. Peradilan adat disini bukanlah peradilan yang terlembaga sebagaimana lazimnya dalam hukum formal. Alasan kenapa jalur informal dipilih adalah karena dianggap lebih efektif dan efesien dari segi waktu, prosedur dan biaya.

Kata kunci: Tindak Pidana, informal, peradilan adat, masyarakat

\section{PENDAHULUAN}

Tindak pidana di Indonesia berkembang secara sistematik. Beberapa bentuk tindak pidana terkadang dianggap sebagai suatu pelanggaran hukum bahkan ada yang menganggap sebagai sekadar suatu kebiasaan. Perkembangan berbagai bentuk tindak pidana di Indonesia mendorong penanggulangan tindak pidana di Indonesia untuk dilakukan secara lebih serius lagi. Namun hingga kini penanggulangan tindak pidana di Indonesia belum menunjukkan titik terang melihat masih tingginya angka tindak pidana yang terjadi di Indonesia.

Upaya mengatasi tindak pidana semestinya tidak terfokus pada program dan upaya yang dicanangkan pemerintah saja. Upaya penanggulangan kejahatan selama ini dilakukan secara penal dan non penal. Upaya yang lebih efektif untuk dilakukan adalah dengan memanfaatkan tradisi yang ada dalam masyarakat sebagai suatu nilai luhur yang ada dalam masyarakat. Secara umum penegakan hukum tidak akan berhasil apabila dilakukan tidak memperhatikan atau mengabaikan nilai nilai kultural dan moral. Nilai kultural memegang peran yang penting dalam penegakan hukum. Penegakan hukum melibatkan nilai nilai, gagasan gagasan, sikap dan prilaku yang terkait dengan hukum. Friedman mengkonsepkan hal tersebut dengan budaya hukum (legal Culture). (Law rence M. Friedman, 1975:87)

Nilai-nilai kultural banyak ditemui pada masyarakat adat di Indonesia terutama masyarakat yang berada pada tingkat pemerintahan terendah. Berbagai persoalan hukum ditemui juga pada masyarakat yang terdapat pada pemerintahan nagari di Sumatera Barat. Salah satu persoalan hukum yang ada adalah berbagai bentuktindak pidana seperti perkelahian, pencurian, kesusilaan dan lain lain. Banyak kasus tindak pidana di pemerintahan nagari yang diselesaikan dengan jalur informal melalui berbagai metode yang diterapkan pada masing-masing daerah tersebut.

Konsep The Looking-Glass Self (Diri yang Seperti Cermin Pantul), menurut Cooley, menyatakan institusi-institusi sosial yang utama ialah bahasa, keluarga, industri, pendidikan, agama, dan hukum. Sementara institusi-institusi tersebut membentuk 'fakta-fakta dari masyarakat' yang bisa dipelajari oleh studi sosiologis, mereka juga merupakan produk-produk yang ditentukan dan dibangun oleh pikiran publik. Menurut Cooley, institusi-institusi tersebut merupakan hasil dari organisasi dan kristalisasi dari pikiran yang membentuk adatadat kebiasaan, simbol-simbol, kepercayaan-kepercayaan, dan sentimen-sentimen perasaan yang tahan lama. ( $M$. FrancisAbraham. 1982:68)

Oleh karena itu, institusi-institusi tersebut merupakan kreasi-kreasi mental dari individu-individu dan dipelihara melalui kebiasaan-kebiasaan manusiawi dari pikiran yang hampir selalu dilakukan secara tidak sadar karena sifat kedekatannya dengan diri kita (familiarity). Seperti yang ditegaskan oleh Cooley, ketika institusi-institusi masyarakat dipahami terutama sebagai kreasi-kreasi mental, maka individu bukanlah semata-mata efek dari struktur sosial, namun juga merupakan seorang kreator dan pemelihara struktur sosial tersebut. Intinya, Cooley mengkonsentrasikan kemampuan-kemampuan analitiknya terhadap perkembangan dari diktum fundamentalnya, yaitu "Imajinasiimajinasi yang saling dimiliki oleh orang-orang merupakan fakta-fakta yang solid dari masyarakat." Dalam bukunya yang pertama, Human Nature and the Social Order, dia terfokus pada teori mengenai diri-yang-bersifat-sosial (social-self), yakni makna "Aku" sebagaimana yang teramati dalam pikiran dan perbincangan sehari-hari.

Persoalan hukum bukan hanya sekedar masalah lembaga hukum dan organ organ negara melainkan juga menyangkut upaya penegakan keadilan yang bersifat informal. Proses penyelesaian tindak pidana melalui jalur informal tersebut merupakan suatu bentuk kearifan lokal masyarakat dalam proses penegakkan hukum. 


\section{RUMUSAN MASALAH}

Berbagai persoalan hukum di tengah masyarakat menimbulkan kebutuhan masyarakat terhadap hukum. Keterbatasan lembaga aparat penegak hukum membuat perlunya peningkatan partisipasi aktif masyarakat untuk menegakkan hukum. Diantaranya penyelesaian tindak pidana melalui jalur informal. Permasalahan yang ada adalah bagaimana ciri khas dari penyelesaian tindak pidana melalui jalur informal tersebut dan bagaimana efektifitas penyelesaian tindak pidana secara informal tersebut terhadap penegakan hukum.

\section{METODE PENELITIAN}

Penelitian ini merupakan penelitian hukum sosiologis (penelitian hukum empiris). Pendekatan yang digunakan adalah pendekatan deskriptif-analitis. Jenis data yang digunakan adalah data primer dan data sekunder. Teknik pengumpulan data adalah dengan observasi dan wawancara. Wawancara dilakukan dengan tokoh adat, polisi sektor di nagari, dan Wali Nagari. Observasi dilakukan terhadap proses penyelesaian tindak pidana oleh lembaga adat. Lokasi penelitian adalah di 7 Nagari di Sumatera Barat. Analisa data yang telah diperoleh dipergunakan teknik analisis kualitatif, yaitu dimaksudkan sebagai analisis terhadap data secara rasional dengan menggunakan pola berpikir tertentu.

\section{HASIL PENELITIAN DAN ANALISIS}

\section{A. Bentuk Penyelesaian Kasus Tindak Pidana secara Informal di Peradilan Adat}

Secara umum menurut Alfan M iko (Alfan Miko, 199927), sejak Nagari-nagari di M inangkabau dipecah-pecah pada tahun 1983 menjadi desa, berbagai keluhan terlontar dari masyarakat setempat. Keluhan itu mempertegas bahwa nagari bagi orang M inangkabau bukan saja sekadar sebutan untuk sebuah wilayah administratif, melainkan sebuah lingkungan sosio-kultural yang sarat dengan nilai, simbol, dan kebanggaan. Bahkan nagari menjadi sebuah penanda bagi keberadaan seseorang orang, sesuatu yang tetap dipelihara seperti kartu identitas diri, betapapun lamanya ia telah meninggalkan nagari tersebut. Setelah nagari berubah menjadi beberapa desa, keluhan bukan saja muncul karena kesulitan anak nagari menyesuaikan diri dengan lingkungan administratif barunya, tapi juga karena desa dirasakan sebagai sebuah simbol kekuasaan yang dipaksakan untuk diterima.

Di dalam Surat Keputusan Gubernur Sumatera Barat No. 2/desa/Gsb/Prt-1963 tentang Peraturan Nagari-Nagari dalam Daerah Sumatera Barat dijelaskan bahwa nagari adalah:

Suatu daerah kesatuan masyarakat hukum adat, atau suatu daerah pemerintahan yang terendah akibat dari berlakunya suatu peraturan perundang-undangan yang mempunyai batas-batas tertentu, berhak mengurus rumah tangganya, memilih penguasanya, dan mempunyai harta benda sendiri.

Jadi Nagari merupakan kesatuan masyarakat hukum adat yang memiliki susunan asli khususnya di wilayah daratan Sumatera Barat yang sejak dahulu sudah dikenal. Pada Undang-undang Nomor 5 Tahun 1979 tentang Pemerintahan Desa diberlakukan di wilayah propinsi Sumatera Barat berdasarkan Surat Keputusan Gubernur Sumatera Barat nomor 162/GSB/1983, keberadaan Nagari sebagai kesatuan masyarakat hukum adat dipertahankan keutuhannya dengan Peraturan Daerah Sumatera Barat Nomor 13 tahun 1983 tentang Nagari Sebagai Kesatuan M asyarakat Hukum Adat dalam Propinsi Sumatera Barat, dalam rangka memelihara dan melestarikan hukum adat serta tradisi yang hidup dan berakar di tengah masyarakat M inangkabau.

Konsep nagari dan realitas lembaga itu sendiri, mengandung apa yang bisa disebut cikal bakal demokrasi. Dalam konsep M inang, ia bukan saja unit budaya terkecil, tetapi unit dasar politik dan administrasi pemerintah serta ekonomi. Konsep mengajarkan tidak ada kekuasaan lain di atasnya. Tiap nagari merupakan republik mini yang otonom. M aka Ranah M inang dengan gugusan nagarinya merupakan bunga rampai satuan politik yang terpencar-pencar. Secara struktural, formasi kekuasaan ini hanya mengikuti garis horizontal dan menolak garis vertikal.(Al Chaidir Zulfikar, 2000:78)

Bergulirnya reformasi, telah mengapungkan hidupnya kembali nuansa lokal di masing-masing daerah. Tidak luput dalam hal ini, termasuk masyarakat dan pemerintahan daerah Sumatera Barat yang saat ini sudah bertekad bulat untuk kembali ke sistem pemerintahan nagari. Sebagaimana sering 
diistilahkan dengan "siriah baliak ka gagangnyo, pinang baliak ka tampuaknyo (sirih pulang ke gagangnya, pinang kembali ke tampuknya)". Peradilan adat mulai banyak dilakukan walaupun tidak mempunyai satu bentuk lembaga tertentu. (wawancara dengan Wali Nagari Tanjung Bingkung 30 April 2016)

Tindak pidana dapat dianggap dan dilihat sebagai suatu bentuk kejahatan yang dapat menghambat usaha-usaha pembangunan menuju kesejahteraan rakyat. Disamping itu tindak pidana juga dapat dilihat sebagai tindakan penyelewengan terhadap kaedah-kaedah hukum dan normanorma sosial lainnya. Dalam perspektif hukum pidana tindak pidana merupakan bentuk kejahatan yang sangat berbahaya baik terhadap masyarakat maupun terhadap bangsa dan negara.

Berdasarkan teori yang dikemukakan Cooley individu dengan saling berinteraksi melalui institusi-institusi sosial kemasyarakatan akan membentuk kebiasaan atau adat berbentuk simbol-simbol. Hal tersebut berakibat timbulnya suatu kebiasaan dalam masyarakat untuk mengatasi persoalan-persoalan yang ada dalam lingkungan mereka. Salah satu kebiasaan-kebiasaan masyarakat yang berbentuk simbol adalah adanya kebiasaan dalam masyarakat untuk menyelesaikan permasalahan yang timbul dalam interaksi sosial mereka dengan cara sendiri.

Interaksi sosial yang terbentuk membuat suatu kebiasaan yang kemudian diikuti secara turun-temurun. Kebiasaan ini dipatuhi dan mengikat setiap warga masyarakat. Berbagai tindak pidana yang terjadi ditengah masyarakat pada umumnya diselesaikan terlebih dahulu melalui peradilan adat. Berdasarkan hasil penelitian bentuk penyelesaian kasus tindak pidana korupsi secara informal yang ditemukan adalah (Observasi di Nagari Paninggahan dan Barulak):

1. Musyawarah masyarakat melalui pemerintah nagari. M usyawarah masyarakat untuk menyelesaikan kasus tindak pidana korupsi dilakukan dengan difasilitasi oleh pemerintah nagari. Pemerintah nagari yang berperan disini adalah Badan Permusyawaratan Nagari (BPN). Badan Permusyawaratan Nagari (BPN) sebagai lembaga legislatif di nagari lebih dianggap netral, karena anggota BPN adalah unsur-unsur tokoh masyarakat dan adat. Korupsi di nagari biasanya dilakukan oleh aparat pemerintahan nagari dan oleh pemegang harta nagari.

2. Sidang adat oleh lembaga Kerapatan Adat Nagari (KAN) Penyelesaian tindak pidana korupsi yang dilakukan oleh KAN biasanya terhadap kasus kasus korupsi yang berkaitan dengan harta benda dalam kekuasaan adat.

3. Pengenaan sanksi adat secara langsung berupa sanksi sosial.

Pengenaan sanksi dilakukan tanpa melalui rapat atau musyarawah adat, tapi dijatuhkan secara langsung berdasarkan kesepakatan adat atau ketentuan adat yang telah ditetapkan sebelumnya. Sanksi adat bagi kasus korupsi biasanya disamakan dengan sanksi bagi tindak pidana pencurian. Bedanya adalah ditambah dengan beberapa bentuk sanksi lainnya.

4. Tindakan langsung yang dilakukan oleh masyarakat untuk mengatasi terjadinya tindak pidana.

Tindakan langsung masyarakat tersebut dapat dicontohkan yang dilakukan terhadap pelaku tindak pidana korupsi dana nagari. Perbuatan ini dapat dilihat dari tindakan masyarakat dengan menahan sepeda motor milik bendaharawan sebuah nagari sebagai jaminan sampai dana yang hilang sebanyak lebih kurang 5 (lima) juta rupiah dipertanggung jawabkan dan dikembalikan. Selain itu masyarakat juga mengenakan sanksi sosial dengan mengumumkan di tempat tempat yang dijangkau oleh umum, bahwa telah terjadi tindak pidana korupsi yang dilakukan oleh bendaharawan tadi. Hal ini jelas telah memukul mental si pelaku korupsi. Tindakan tersebut jauh lebih cepat daripada mengadukannya ke aparat penegak hukum yang mungkin membutuhkan waktu dan biaya yang lebih besar daripada jumlah yang hilang.

Tabel 1. Rekapitulasi bentuk penyelesaian yang dilakukan

\begin{tabular}{cll}
\hline NO & BENTUK PENYELESAIAN & $\begin{array}{l}\text { JUMLAH } \\
(\%)\end{array}$ \\
\hline 1 & $\begin{array}{l}\text { Musyawarah masyarakat melalui } \\
\text { pemerintah nagari }\end{array}$ & $20 \%$ \\
2 & $\begin{array}{l}\text { Sidang adat oleh lembaga } \\
\text { Kerapatan Adat Nagari (KAN) }\end{array}$ & $15 \%$ \\
3 & $\begin{array}{l}\text { Pengenaan sanksi adat secara } \\
\text { langsung berupa sanksi sosial }\end{array}$ & $20 \%$ \\
4 & $\begin{array}{l}\text { Tindakan langsung yang dilakukan } \\
\text { oleh masyarakat untuk mengatasi } \\
\text { tindak pidana korupsi }\end{array}$ & $45 \%$ \\
\hline
\end{tabular}


Sumber: $\mathrm{H}$ asil $\mathrm{O}$ bservasi di Nagari Paninggahan dan Barulak

Bentuk penyelesaian tindak pidana yang dilakukan oleh masyarakat melalui peradilan adat seuai dengan Teori Interaksionisme simbolik. Inti pandangan pendekatan Teori Interaksionisme simbolik adalah individu. Para ahli di belakang perspektif ini mengatakan bahwa individu merupakan hal yang paling penting dalam konsep sosiologi hukum. Mereka melihat bahwa individu adalah obyek yang bisa secara langsung ditelaah dan dianalisis melalui interaksinya dengan individu yang lain. Individu-individu berinteraksi dengan menggunakan simbol-simbol, yang di dalamnya berisi tanda-tanda, isyarat dan kata-kata. Interaksionisme simbolik pada hakikatnya merupakan sebuah perspektif yang bersifat sosial-psikologis yang terutama relevan untuk penyelidikan sosiologis. (Esmi Warassih Pujirahayu, 2005:28)

Teori ini akan berurusan dengan struktur-struktur sosial, bentuk-bentuk kongkret dari perilaku individual atau sifatsifat batin yang bersifat dugaan, interaksionisme simbolik memfokuskan diri pada hakekat interaksi, pada pola-pola dinamis dari tindakan sosial dan hubungan sosial. Interaksi sendiri dianggap sebagai unit analisis; sementara sikap-sikap diletakkan menjadi latar belakang. Baik manusia dan struktur sosial dikonseptualisasikan secara lebih kompleks, lebih tak terduga, dan aktif jika dibandingkan dengan perspektifperspektif sosiologis yang konvensional. Penyelesaian tindak pidana oleh masyarakat terbentuk karena adanya interaksi dan konsep konsep sosial yang menjadi makna tersirat dalam masyarakat.

M emahami makna yang tersirat dari interaksi masyarakat ditemukan bentuk proses penyelesaian perkara. Proses penyelesaian perkara tindak pidana diketahui dengan metode observasi partisipasi. Peneliti melibatkan diri dalam setiap proses penyelesaian tindak pidana korupsi di wilayah penelitian. Proses penyelesaian kasus korupsi secara informal di nagari merupakan sebuah rangkaian sistem. Sistem tersebut dapat dilihat pada sistem adat. Di beberapa Nagari ditemukan adanya partisipasi masyarakat dalam penanggulangan kejahatan yang diwujudkan dalam peran lembaga adat. Kerapatan Adat Nagari (KAN) di sini telah melakukan penyelesaian kasus tindak pidana korupsi pada nagari melalui pemuka pemuka nagari sendiri. Begitu juga halnya dengan badan permusyawaratan Nagari (BPN) yang melakukan penyelesaian kasus korupsi melalui musyawarah dengan masyarakat. Contoh kasus adalah pada masyarakat tigo balai yang melaporkan Wali Nagari yang diduga melakukan korupsi dana bantuan goro badunsanak dari pemerintah Kabupaten. Kasusini hanya diselesaikan secara musyawarah di tingkat nagari.

Pada penyelesian ini tokoh adat dan tokoh pemerintahan nagari melakukan perannya masing masing. Seperti diungkapakn dalam teori Peran (Role Theory) menjelaskan dampak masyarakat atas perilaku kita dalam hubungannya dengan peran, namun jauh sebelumnya Robert Linton ( $M$. Francis Abraham, 1982:36), seorang antropolog, telah mengembangkan Teori Peran. Teori Peran menggambarkan interaksi sosial dalam terminologi aktor-aktor yang bermain sesuai dengan apa-apa yang ditetapkan oleh budaya. Sesuai dengan teori ini, harapan-harapan peran merupakan pemahaman bersama yang menuntun kita untuk berperilaku dalam kehidupan sehari-hari.

Menurut teori ini seseorang yang mempunyai peran tertentu misalnya sebagai dokter, mahasiswa, orang tua, wanita, dan lain sebagainya, diharapkan agar seseorang tadi berperilaku sesuai dengan peran tersebut. Mengapa seseorang mengobati orang lain, karena dia adalah seorang dokter. Jadi karena statusnya adalah dokter maka dia harus mengobati pasien yang datang kepadanya. Perilaku ditentukan oleh peran sosial.

Peran sosial bagi seorang individu dapat dilakukan menurut beberapa kategori. Kategori tersebut misalnya menurut usia, kedudukan di tengah masyarakat, strata sosial dan lain sebagainya. Peran tersebut termasuk juga peran untuk ikut serta mencipatakan ketertiban di lingkungan sosial mereka, misalnya peran untuk turut serta menanggulangi kejahatan. Peran tersebut mengakibatkan timbulnya kebiasaan berbentuk tata cara atau adat yang dilakukan untuk menyelesaikan sebuah kasustindak pidana. Masing-masing masyarakat konsisten dengan perannya untuk ikut serta aktif dalam usaha penyelesaian kasus tindak pidana yang terjadi. 
Adapun proses tersebut dapat dilihat pada skema berikut: 1.Musyawarah nagari

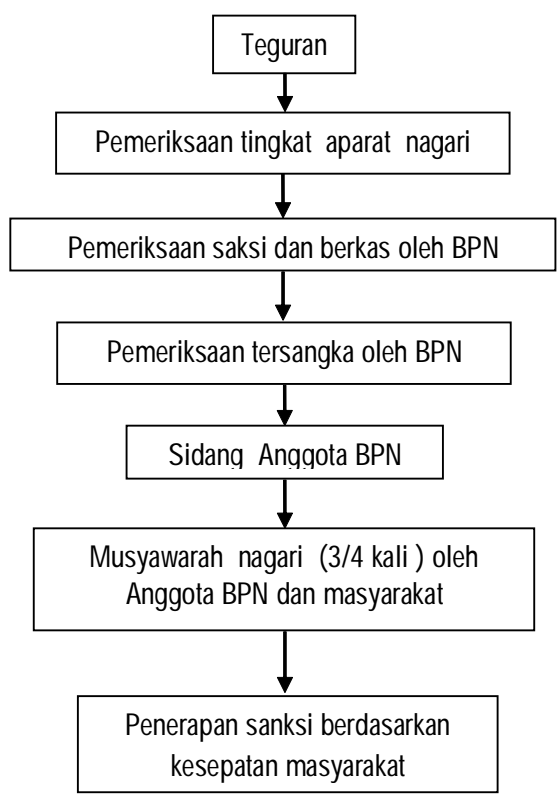

2. Sidang adat

Pada dasarnya sidang adat sama dengan musyawarah nagari, yang membedakan adalah penyelesaian kasus oleh tokoh adat dan sanksi yang dijatuhkan adalah menurut aturan adat. M enurut hukum adat M inangkabau Korupsi di analogikan dengan mencuri. Proses oleh Kerapatan Adat Nagari (KAN) dapat digambarkan sebagai berikut:

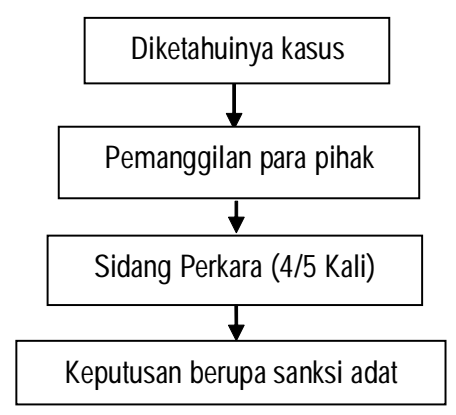

\section{B. Efektifitas Penyelesaian Tindak Pidana Secara Informal Tersebut Terhadap Penegakan H ukum.}

Kasus tindak pidana yang terjadi di daerah berada pada jumlah yang sedikit. Sebagian besar kasus diselesaikan secara informal. Berdasarkan kuisioner yang diberikan kepada responden aparat nagari, tokoh adat dan masyarakat, dapat disimpulkan ada 4 (empat) pertimbangan kenapa jalur informal lebih dipilih untuk menyelesaikan kasustindak pidana korupsi. Pertimbangan tersebut yaitu lebih cepat, biaya ringan, aman dari praktek mafia peradilan, efektifitas sanksi yang berat dan membuat jera baik bagi pelaku ataupun masyarakat lainnya, prosedur yang jelas dan terbuka dengan melibat seluruh komponen masyarakat.

Teori Bekerjanya Hukum menurut Robert B Siedman, basis bekerjanya hukum adalah masyarakat. Hukum akan dipengaruhi oleh faktor-faktor atau kekuatan sosial mulai dari tahap pembuatan sampai dengan pemberlakuan. Kekuatan sosial akan berusaha masuk dalam setiap proses legislasi secara efektif dan efisien. Hal ini yang mendasari kenapa jalur informal banyak ditempuh oleh masyarakat pada strata pemerintahan terendah untuk penyel esaian suatu perkara pidana terutama tindak pidana korupsi.

Berdasarkan basis bekerjanya hukum adalah masyarakat, maka hukum akan dipengaruhi oleh faktor-faktor atau kekuatan sosial mulai dari tahap pembuatan sampai dengan pemberlakuan. Kekuatan sosial akan berusaha masuk dalam setiap proses legislasi secara efektif dan efisien. Peraturan yang dikeluarkan diharapkan sesuai dengan keinginan, tetapi efek dari peraturan tersebut tergantung dari kekuatan sosial seperti bila budaya hukumnya baik, maka hukum akan bekerja dengan baik pula, tetapi sebaliknya apabila kekuatannya berkurang atau tidak ada maka hukum tidak akan bisa berjalan. Karena masyarakat sebagai basis bekerjanya hukum.

Di M inangkabau dikenal istilah “Batanggo naik bajanjang turun" (bertangga naik berjenjang turun) artinya suatu masalah dalam nagari harus diselesaikan menurut tahapan yang jelas. Tahapan mulai dari kelompok masyarakat yang sederhana sampai kepada kelompok masyarakat yang besar. Hal tersebut dapat dilihat pada usaha masyarakat dalam menyelesaikan sebuah perkara yang diduga sebagai tindak pidana korupsi pada tingkat terendah dulu sebelum melaporkan kepada pihak berwenang untuk diproses hukum secara formal.

Sikap yang ditunjukkan masyarakat terhadap hukum terkadang berdasarkan kondisi sosial masing-masing atau 
hanya didasarkan pada bentuk kearifan lokal yang sudah ada. Masyarakat kurang memahami tentang aturan hukum secara positif, terdapat angka yang cukup tinggi untuk berbagai bentuk kejahatan pada daerah marjinal. (Fitriati, 2014: 563)

Kelompok masyarakat mewujudkan partisipasinya dengan mengambil tindakan untuk menyelesaikan kasus tindak pidana korupsi. Tindakan yang mereka perbuat adalah berdasarkan pengalaman bahwa bila mereka menempuh jalur hukum sering menemui kegagalan. Setiap kasus korupsi yang terjadi masyarakat berpartisipasi mengupaya penyelesaian secara informal dulu. Apabila jalur informal menemui kegagalan barulah dilakukan pelaporan kepada pihak yang berwenang. Pelaporan yang dilakukan sering menemui kendala. Banyak kasus yang dilaporkan masyarakat yang kemudian tidak diproses dengan berbagai alasan perkara tersebut hilang tanpa diketahui kelanjutannya. M asyarakat kurang mendapat informasi publik tentang proses pidana tindak pidana korupsi yang telah mereka laporkan.

Penyelesaian secara informal lebih bersifat terbuka dan berlangsung cepat. Masyarakat menganggap prosesini lebih aman dari praktek suap dan sogok. Dikarenakan pemeriksaan dan keputusan yang diambil adalah melalui musyawarah yang dilakukan dengan melibatkan seluruh masyarakat beserta tokoh-tokohnya serta tokoh adat. Masyarakat merasa lebih baik menyelesaikan kasus tindak pidana korupsi pada daerah mereka secara non-litigasi. Sanksi yang dijatuhkan terkadang lebih berat karena sanksi lebih kepada penderitaan terhadap moral pelaku dan keluarganya secara sosial.

\section{Tabel 2. Pertim bangan memilih jalur informal.}

\begin{tabular}{llll}
\hline CEPAT \& & AMAN DARI & EFEKTIFITAS & PROSEDUR YANG \\
MURAH & KKN & SANKSI & JELAS \\
\hline $53 \%$ & $25 \%$ & $10 \%$ & $12 \%$ \\
\hline
\end{tabular}

Sumber: K uisioner pada wilayah penelitian

Pemilihan jalur informal penyelesaian tindak pidana melalui peradilan menunjukkan karakter sendiri yaitu adanya ciri keterlibatan semua tokoh masyarakat, tokoh adat dan tokoh pemerintahan daerah dalam proses tersebut. Hal ini juga dirasakan lebih efektif dalam hal penegakkan hukum karena lebih dipatuhi oleh masyarakat baik terhadap sanksi ataupun terhadap proses yang diselenggarakan.

\section{KESIMPULAN}

Berdasarkan uraian pada hasil dan pembahasan di atas maka dapat diambil simpulan tiga kesimpulan. Pertama, bentuk penyelesaian kasus tindak pidana secara informal di pemerintahan nagari adalah dengan M usyawarah masyarakat melalui pemerintah nagari. Kedua, sidang adat oleh lembaga Kerapatan Adat Nagari (KAN). Ketiga, pengenaan sanksi adat secara langsung berupa sanksi sosial dan tindakan langsung yang dilakukan oleh masyarakat untuk mengatasi tindak pidana korupsi

Proses penyelesaian kasus secara informal tersebut adalah dilakukan dengan pemeriksaan terlebih dahulu oleh aparat masyarakat dan tokoh adat. Apabila pemeriksaan bukti berupa barang bukti dan keterangan saksi maka tahap selanjutnya adalah dengan mengadakan musyawarah atau sidang dengan melibatkan masyarakat secara luas. Penyelesaian secara informal menjadi pilihan bagi masyarakat dengan dasar adalah cepat dan murah, aman dari praktek mafia peradilan, efektifitas sanksi dan prosedur yang jelas. Hal ini menunjukan proses penyelesaian tindak pidana dengan peradilan adat sebagai jalur informal dapat menegakkan hokum.

\section{DAFTAR PUSTAKA}

\section{Buku-buku}

Burhani M.S. dan H asbi Lawrens,: t.th, Referensi IImiahPolitik K amus IImiah Populer, Lintas M edia, Jombang Emeraldy C hatra, A dat Selingkar D esa, 1999, Fakultas

IImu Sosial dan IImu Politik Universitas Andalas dan Pusat Studi Pembangunan dan Perubahan Sosial Budaya U nand, Padang

Echols, John M. dan Hassan Shadily, 1990. Kamus Inggris I ndonesia, PT. G ramedia, Jakarta

Esmi Warassih Pujirahayu dalam Pranata H ukum sebuah telaah sosiologis PT Suryandaru utama maret 2005

Lawrence M .Friedman,1975, The legal System, a social science perspective, Russel sage Foundation, N ew York M ariam Webster, 1985, New international dictionary,

$G \& C$ M ariam C o.Publishers Springfield M ass U SA M. Francis A braham. 1982, M odern Sociological Theory (A n Introduction). Oxford: Oxford U niversity Press. Chapter 8.

M ertokusumo, Sudikno, 1999, M engenal H ukum Suatu 
Pengantar, Liberty, Yogyakarta

Soerjono Soekamto, 1993, Faktor-faktor yang M empengaruhi Penegakan H ukum, PT. Raja G rafindo Persada, Jakarta

Zulfikar Al Chaidir, 2000, Federasi atau Disintegrasi; Telaah A wal Wacana U nitaris versus Federalis dalam Prespektif I slam, N asionalisme, $\mathrm{N}$ asionalisme dan Sosial Demokrasi, Jakarta, M adani Pers

Fitriati, M eita Lefi K urnia, Fitra 0 ktoriny, 2014, A plikasi K omunikasi H ukum Sebagai U saha Penegakan H ukum Di Daerah M arjinal, Jurnal Masalah masalah H ukum volume 43 No. 4 (2014)

\section{Peraturan Perundangundangan}

Surat Keputusan G ubernur Sumatera Barat No. 2/ desa/ G sb/ Prt-1963

Peraturan Daerah Sumatera Barat Nomor 13 tahun 1983 tentang Nagari Sebagai Kesatuan Masyarakat Hukum Adat dalam Propinsi Sumatera Barat

Bio Data; Fitriati, lahir di Solok 30 Januari 1974, menamatkan pendidikan Doktor di Universitas Diponegoro pada tahun 2012. Saat ini bekerja sebagai Dosen pada Fakultas Hukum dan Program pascasarjana U niversitas Eka sakti, U niversitas Bung $\mathrm{H}$ atta dan universitas Islam Riau. Bidang ilmu Hukum yang ditekuni adalah IImu H ukum Pidana. Telah meneliti dan menulis berbagai artikel dan buku tentang pemberdayaan masyarakat dalam usaha penegakan hokum pidana dan penaggulangan kejahatan. 